American Journal of Economics and Business Administration 3 (1): 40-46, 2011

ISSN 1945-5488

(C) 2010 Science Publications

\title{
Assessing the Usability and Accessibility of Malaysia E-Government Website
}

\author{
Wan Abdul Rahim Wan Mohd Isa, Muhammad Rashideen Suhami, \\ Noor Ilyani Safie and Siti Suhada Semsudin \\ Systems Science Studies, \\ Faculty of Computer and Mathematical Sciences, \\ University Technology MARA (UiTM) Malaysia, \\ 40450 Shah Alam, Selangor, Malaysia
}

\begin{abstract}
Problem statement: With the proliferation number existence of Malaysia e-government websites, the usability and accessibility feature may has been overlooked by website developers. Approach: The main objective of this study is to investigate the usability and accessibility of Malaysia e-government websites. The usability measures are being measured by using Nielson usability guideline for the uploading speed and page size of the main page and number of broken links. The accessibility is measured by using Web Content Accessibility Guidelines 1.0 (WCAG). Samples of 155 Malaysia e-government websites were selected from federal government websites and state government websites available at http://www.malaysia.gov.my. The usability and accessibility of the websites was analyzed by using several automatic evaluation tools such as Websiteoptimization, Axandra and EvalAccess 2.0 tools. Results: The evaluation process revealed several issues on usability and accessibility of Malaysia e-government website. There is high number of usability (speed and number of broken links) and accessibility problems for state website upon comparing to federal website. Conclusion/Recommendation: This study provides few recommendations for further improvement of the usability and accessibility features of e-government website based on the highlighted issues and key findings reported in this study.
\end{abstract}

Key words: Accessibility, e-government, human computer interaction, Malaysia

\section{INTRODUCTION}

With the expansion of the Information and Communication Technology (ICT) globally, many peoples opt to conduct official communications with the government by using the web technology. The web technology provides various benefits of changing the way people study and becomes a tool for government sectors to provide information and services to citizens. There is growing research on accessibility as such for older people (Nasir et al., 2008) and visually impaired person (Nordin et al., 2009). However, these web technologies are not perfect in terms of usability and accessibility. People with physical disabilities such as sight and hearing disabilities might face problem to access and use that website. To solve the usability and accessibility problems, innovative designs are being required for web developer to make their web site more usable and accessible by everyone including people with disabilities (Lee et al., 2007). Among well-known guideline for accessibility and usability is Web Content Accessibility Guidelines 1.0 (WCAG 1.0) (Robbins, 2006) and Nielson usability guideline (Nielson, 1994; 2000). Thus, the main objective of this study is to investigate the usability and accessibility of Malaysia egovernment websites with reference to the WCAG 1.0 and Nielson usability guideline by using quantitative measures and automatic evaluation tools.

Literature review: E-Government term: In general, the term "e-government" is defined as "streamlining government by providing efficient and effective services and information to citizens and business through advanced technology" (Blackstone et al., 2005). It presents a way for governments to provide convenient access to services via Internet and wireless communication technology (Siau and Long, 2006).

As shown in Table 1, there are growing numbers of research on e-government studies in various parts of

Corresponding Author: Wan Abdul Rahim Faculty of Computer and Mathematical Sciences,

University Technology MARA Malaysia, 40450 Shah Alam, Selangor, Malaysia 
Am. J. of Economics and Business Administration 3 (1): 40-46, 2011

Table 1: E-government accessibility studies

\begin{tabular}{|c|c|}
\hline Country & Studies \\
\hline Australia & $\begin{array}{l}\text { E-government accessibility in Australia } \\
\text { and China (Shi, 2006) }\end{array}$ \\
\hline China & $\begin{array}{l}\text { Accessibility of Chinese government } \\
\text { sites (Shi, 2007) }\end{array}$ \\
\hline Czech Republic & $\begin{array}{l}\text { Accessibility of e-government Czech } \\
\text { sites (Kopackova et al., 2009) }\end{array}$ \\
\hline Ireland & $\begin{array}{l}\text { Accessibility of local e-government } \\
\text { Ireland sites (Paris, 2006) }\end{array}$ \\
\hline Japan & $\begin{array}{l}\text { Policy issues regarding e-government } \\
\text { and Web accessibility in Japan } \\
\text { (Koga, 2006) }\end{array}$ \\
\hline Korea & $\begin{array}{l}\text { Accessibility Evaluation of Korean } \\
\text { e-government (Lee } \text { et al., 2007) }\end{array}$ \\
\hline Malaysia & $\begin{array}{l}\text { Evaluation of e-government websites in } \\
\text { Malaysia (Ahmad Bakeri, 2008), (Wan } \\
\text { Abdul Rahim, Muhammad Rashideen } \\
\text { and Noor Ilyani, 2010) (Latif and } \\
\text { Masrek, 2010) }\end{array}$ \\
\hline Nepal & $\begin{array}{l}\text { Evaluating the Accessibility of } \\
\text { Government sites of Nepal (Shah and } \\
\text { Shakya, 2007) }\end{array}$ \\
\hline Saudi Arabia and Oman & $\begin{array}{l}\text { E-Government Website Accessibility of } \\
\text { Saudi Arabia and Oman } \\
\text { (Abanumy et al., 2005) }\end{array}$ \\
\hline South Africa & $\begin{array}{l}\text { Evaluating South African government } \\
\text { sites (Korsten and Bothma, 2007) }\end{array}$ \\
\hline Taiwan & $\begin{array}{l}\text { Accessibility Diagnosis on the Taiwan } \\
\text { Government Sites (Chen } \text { et al., 2005) }\end{array}$ \\
\hline USA & $\begin{array}{l}\text { Federal Electronic Government } \\
\text { Accessibility (Becker, 2008) } \\
\text { Accessibility of Alabama government } \\
\text { sites (Potter, 2002) }\end{array}$ \\
\hline
\end{tabular}

regions, worldwide. In Malaysia, the E-government projects are closely monitored by Malaysian Administrative Modernization and Management Planning Unit (MAMPU) of the Prime Minister's Department (Ahmad Bakeri, 2008). One of the MAMPU initiatives is My Government portal (http://www.gov.my). The portal is being used for citizens accessing government information and online services and received nearly 6.5 million visitors, as of May 2008 (Ahmad Bakeri, 2008). However, the state of the accessibility level of federal, state and local authorities listed inside the portal is yet to be unknown.

Usability traits: There are growing interests of research of usability measurement in website (Wan Abdul Rahim, et al., 2009a; 2009b; 2010). Usability of a system is indicated with ease of learning, efficient to use, easy to remember, low usage error rate and pleasant to use (Nielson, 1994). The usability measures are being measured by using Nielson usability guideline for the uploading speed and page size of the main page and number of broken links (Nielson, 2000). In terms of speed, Nielson (2000) studies showed that users beg to speed up page download (Nielson, 2000). Nielson (2000) also noted the work of Robert at the Fall Joint
Table 2: WCAG 1.0 guidelines (Robbins, 2006)

\begin{tabular}{ll}
\hline No & Guideline \\
\hline 1 & $\begin{array}{l}\text { Provide equivalent alternatives to auditory and visual } \\
\text { content. }\end{array}$ \\
2 & Don't rely on color alone. \\
3 & Use markup and style sheets and do so properly. \\
4 & Clarify natural language usage \\
5. & Create tables that transform gracefully. \\
6. & Ensure that pages featuring new technologies transform \\
7. & gracefully. \\
8. & Ensure user control of time-sensitive content changes. \\
9. & Ensure direct accessibility of embedded user interfaces. \\
10. & Design for device-independence. \\
11. & Use W3C technologies and guidelines. \\
12. & Provide context and orientation information. \\
13. & Provide clear navigation mechanisms. \\
14. & Ensure that documents are clear and simple. \\
\hline
\end{tabular}

Computer in 1968 in which it the minimum of ten seconds, is about the limit time for keeping user's attention focused on navigating the site. With relation to page size attribute, there is a need to keep page size below $34 \mathrm{~KB}$ for modem users (Nielson, 2000).

Website accessibility: In general, World Wide Web Consortium (W3C) defined web accessibility as "accessibility means that people with disabilities can perceive, understand, navigate and interact with the web". The W3C has produced a set of international standards for the design of accessible Web content - the Web Content Accessibility Guidelines 1.0 (WCAG 1.0) (Robbins, 2006). Published in 1999, WCAG 1.0 has become an important reference for web accessibility for web community (Centeno et al., 2005), influencing policy and legislation (Alexander, 2003) and have been used for developing accessibility authoring and checking tools (Tillett, 2001).

WCAG 1.0 is an internationally accepted standard that consists of 14 guidelines that provide specifications on how to develop an accessible site (Thatcher, 2002). These 14 guidelines are divided into Priority 1, 2 and 3 checkpoints, with Priority 1 being the most important. According to Cartel and Markel (2001), the number of checkpoints varies between guidelines (Carter and Markel, 2001). Table 2 shows the 14 guidelines, specified by WCAG 1.0 (Robbins, 2006). Each guideline includes one or more checkpoints with 65 checkpoints in total. The checkpoints are categorized into three priority levels based on the checkpoint's impact on accessibility. Checkpoints under the same guideline may be categorized into different priority levels (Thatcher, 2002):

Priority 1 (16 checkpoints): A Web content developer must satisfy these checkpoints specified in Priority 1. Otherwise, it will rather difficult for user to access information in the document. Satisfying this checkpoint 
Am. J. of Economics and Business Administration 3 (1): 40-46, 2011

Table 3: Sample of Malaysia government websites

\begin{tabular}{llr}
\hline Administrative & Frequency & $(\%)$ \\
\hline Federal & 25 & 16.1 \\
State & 130 & 83.9 \\
Total & 155 & 100.0 \\
\hline
\end{tabular}

is a basic requirement for some groups to be able to use the Web documents.

Priority 2 (30 checkpoints): A Web content developer should also satisfy these checkpoints specified in Priority 2. Otherwise, one or more groups will find it difficult to access information in the document. Satisfying this checkpoint will remove significant barriers to accessing Web documents

Priority 3 (19 checkpoints): A Web content developer may address this checkpoint. Otherwise, one or more groups will find it somewhat difficult to access information in the document. Satisfying this checkpoint will improve access to Web documents. However, for the scope of the study, we only focus on error or automatic tests for Priority 1 and Priority 2

\section{MATERIALS AND METHODS}

The evaluation process was conducted between 15 August 2009 and 10 September 2009. The time of evaluation is between $10 \mathrm{pm}$ and $12 \mathrm{am}$. Samples of 155 websites were selected by using convenient sampling from Malaysia government portal (http://www.malaysia.gov.my). The websites comprised of federal government and state government Table 3 shows the composition of the 155 websites in term of their administrative level (Federal/State). The accessibility evaluation process was done by using automatic evaluation tool, EvalAccess 2.0 which is limited to only WCAG 1.0 guidelines. The usability evaluation is websiteoptimization tool; http://www.websiteoptimization.com/services/analyze/ to assess the uploaded speed and page size for the main page. In addition, axandra usability tool which is available at http://www.axandra.com/free-online-seotool/broken-link-checker.php was used to assess the site's broken link.

\section{RESULTS}

Overall usability results: The usability testing includes speed, page size and broken links traits which are based on Nielson (2000) related guideline to web usability (Nielson, 2000). However, only 134 out of 155 websites can be analyzed for usability using the
Table 4: Usability traits

\begin{tabular}{lll}
\hline Usability Traits(Filter) & Freq & Percentage \\
\hline Speed $(14.4 \mathrm{~K})>10 \mathrm{sec}$ & 127 & 94.78 \\
Speed $(28.8 \mathrm{~K})>10 \mathrm{sec}$ & 126 & 94.03 \\
Speed $(33.6 \mathrm{~K})>10 \mathrm{sec}$ & 126 & 94.03 \\
Speed $(56 \mathrm{~K})>10 \mathrm{sec}$ & 125 & 93.28 \\
Speed $(128 \mathrm{~K})>10 \mathrm{sec}$ & 123 & 91.79 \\
Speed $(1.44 \mathrm{Mbps})>10 \mathrm{sec}$ & 82 & 61.19 \\
Broken Link $>=1$ & 97 & 72.39 \\
Page size $>34 \mathrm{~KB}$ & 125 & 93.28 \\
\hline
\end{tabular}

Table 5: Presence of e-government usability error (type)

\begin{tabular}{|c|c|c|c|c|c|}
\hline \multirow[b]{3}{*}{ Guideline } & \multirow[b]{3}{*}{ Violation } & \multicolumn{4}{|c|}{ Government type } \\
\hline & & \multicolumn{2}{|c|}{ Federal state } & \multirow[b]{2}{*}{ Count } & \multirow[b]{2}{*}{$\begin{array}{l}\text { Within } \\
\text { type }(\%)\end{array}$} \\
\hline & & Count & $\begin{array}{l}\text { Within } \\
\text { type (\%) }\end{array}$ & & \\
\hline \multirow[t]{2}{*}{ Speed 1.44 Mbps } & Y & 22 & 91.7 & 60 & 54.5 \\
\hline & $\mathrm{N}$ & 2 & 8.3 & 50 & 45.5 \\
\hline Total & & 24 & 100.0 & 110 & 100.0 \\
\hline \multirow[t]{2}{*}{ Broken link } & $\mathrm{Y}$ & 21 & 87.5 & 77 & 70.0 \\
\hline & $\mathrm{N}$ & 3 & 12.5 & 33 & 30.0 \\
\hline Total & & 24 & 100.0 & 110 & 100.0 \\
\hline
\end{tabular}

aforementioned tools due to inaccessibility of the site during evaluation period. In general, the observed data from Table 4 shows that the overall usability traits used by the Malaysian e-government websites are quite poor. More than $90 \%$ of the Malaysia e-government websites have uploaded time duration of more than 10 seconds and have existence of broken links. In addition, 125 of the Malaysia e-government websites have main page size, uploaded in more than $34 \mathrm{~KB}$. These results prove that usability traits are less than being considerate in Malaysia e-government web design by website developer.

Usability results for federal and states government website: As shown in Table 5, only speed $1.44 \mathrm{Mbs}$ and broken links are valid and meet the assumption for the data interpretation as suggested by Pallant (2008) for cross tabulation analysis. The findings also revealed that websites under state government may need to increase the accessibility level of the sites compared to federal government websites due to the high number of accessibility errors reported in this study. This assumption is based of the comparison made with the percentage of error showed for State websites are higher than federal websites for the checklist shown in Table 5 .

Accessibility analysis on e-government website: Table 6 and 7 revealed the accessibility analysis and summary description of the violated accessibility checkpoints based on the sampling of 155 websites.

However, 7 critical checkpoints had being identified as among being highly violated by Malaysian 
Am. J. of Economics and Business Administration 3 (1): 40-46, 2011

Table 6: Accessibility analysis on e-government site

\begin{tabular}{|c|c|c|c|}
\hline \multirow{2}{*}{$\begin{array}{l}\text { Priority } \\
1\end{array}$} & \multirow{2}{*}{$\begin{array}{l}\text { Checkpoint with } \\
\text { HTML element and } \\
\text { attribute } \\
1.1 \text { Image, Alt }\end{array}$} & \multicolumn{2}{|c|}{$\begin{array}{l}\text { Number and percentage } \\
\text { of websites } \\
\text { violates this checkpoint }\end{array}$} \\
\hline & & 128 & 82.6 \\
\hline & 1.1 Area, Alt & 17 & 11.0 \\
\hline & 1.1 Applet, Alt & 2 & 1.3 \\
\hline & 1.1 Button, Alt & 2 & 1.3 \\
\hline \multirow[t]{3}{*}{2} & 3.4 Table, Border & 145 & 93.5 \\
\hline & 3.4 Table, Cell pad & 143 & 92.3 \\
\hline & 3.4 Table, Width & 116 & 74.8 \\
\hline \multirow[t]{10}{*}{2} & $6.4 \mathrm{~A}$, on click & 58 & 37.4 \\
\hline & $6.4 \mathrm{~A}$, on mouse out & 34 & 21.9 \\
\hline & $6.4 \mathrm{~A}$, on mouse over & 36 & 23.2 \\
\hline & 6.4 A, on mouse down & 2 & 1.3 \\
\hline & $6.4 \mathrm{~A}$, on mouse up & 1 & 0.6 \\
\hline & 6.4 Area, on click & 1 & 0.6 \\
\hline & 6.4 Input, on click & 40 & 25.8 \\
\hline & 6.4 Input, on key press & 1 & 0.6 \\
\hline & 6.4 Input, on mouse out & 7 & 4.5 \\
\hline & 6.4 Input, on mouse over & 7 & 4.5 \\
\hline 2 & 7.2 Blink & 4 & 2.6 \\
\hline 2 & 7.3 Marquee & 51 & 32.9 \\
\hline \multirow[t]{2}{*}{2} & 10.1 A, Target & 115 & 74.2 \\
\hline & 10.1 Area, Target & 8 & 5.2 \\
\hline \multirow[t]{5}{*}{2} & 11.2 Applet & 2 & 1.3 \\
\hline & 11.2 Base, font & 1 & 0.6 \\
\hline & 11.2 Font & 110 & 71.0 \\
\hline & 11.2 Center & 44 & 28.4 \\
\hline & $11.2 \mathrm{U}$ & 34 & 21.9 \\
\hline \multirow[t]{2}{*}{2} & 12.4 Input, Id & 102 & 65.8 \\
\hline & 12.4 Label, For & 3 & 1.9 \\
\hline 2 & 13.2 Title & 9 & 5.8 \\
\hline
\end{tabular}

Table 7: Summary description of violated checkpoint

\begin{tabular}{lll}
\hline Priority Checkpoint & Description \\
\hline 1 & 1.1 & $\begin{array}{l}\text { Provide text equivalent for non-text } \\
\text { Use relative rather than absolute units in } \\
\text { markup language attribute values and } \\
\text { style sheet property values. }\end{array}$ \\
2 & 3.4 & $\begin{array}{l}\text { For scripts \& applets, ensure that event } \\
\text { handlers are input device-independent. }\end{array}$ \\
2 & 7.2 & $\begin{array}{l}\text { Until user agents allow users to control } \\
\text { blinking, avoid causing content to blink }\end{array}$ \\
2 & 7.3 & $\begin{array}{l}\text { Until user agents allow users to freeze } \\
\text { moving content, avoid movement in pages }\end{array}$ \\
2 & 10.1 & $\begin{array}{l}\text { Until user agents provide the ability to stop } \\
\text { auto-redirect, do not use markup to redirect pages } \\
\text { automatically. Instead, configure the server to } \\
\text { perform redirects. } \\
\text { Avoid deprecated features of W3C technologies. } \\
2\end{array}$ \\
& 11.2 & $\begin{array}{l}\text { Associate labels explicitly with their controls. } \\
\text { Provide metadata to add semantic information } \\
\text { to pages and sites }\end{array}$ \\
\hline
\end{tabular}

e-government websites. The 7 critical checkpoints identified are:

- Image, Alt (Checkpoint 1.1)

- Table, Border (Checkpoint 3.4)

- Table, Cell padding (Checkpoint 3.4)

- Table, Width (Checkpoint 3.4)
- A, Target (Checkpoint 10.1)

- Font (Checkpoint 11.2)

- Input, Id (Checkpoint 12.4)

To protect the anonymity and confidentiality of the name of government websites with critical error, only the type of the government websites are being reported in this study. The next results report the listing of top 5 government websites with these 7 critical errors.

E-Government website with high critical error for checkpoint 1.1 (Image, Alt): According to Table 8, state government websites lead the highest error ranking by having 136, 107 and 105 numbers of errors for "Checkpoint 1.1 (Img, Alt)", respectively. However, federal websites tops the error ranking with 139 errors.

E-Government website with high critical error for checkpoint 3.4 (Table, Border): Table 9 shows the number of errors for websites that violate "Checkpoint 3.4 (Table, Border)". Federal websites is leading the errors with 104, 97, 87 and 83 errors. In general, websites from federal government dominates the Table 9 by violating the checklist the most as compared to state government.

E-Government website with high critical error for checkpoint 3.4 (Table, Cell Padding): The websites with high critical error for "Checkpoint 3.4 (Table, Cell Padding)" are vividly displayed in Table 10, which reports Federal websites to have significant 104, 96, 90 and 82 errors, respectively. Here, the websites from federal government also dominates the Table 10 by violating the checklist the most as compared to state government websites.

E-Government website with high critical error for checkpoint 3.4 (Table, Width): Table 11 reports federal websites tops the error ranking with 62 errors. However, the websites from states government dominates the Table 11 by violating the checklist the most as compared to federal government with 48,42 and 40 errors.

E-Government website with high critical error for checkpoint 10.1 (A, Target): In general, Table 12 shows federal websites dominating the error ranking. The federal government websites with critical errors for "Checkpoint 10.1 (A, Target)" are being reported in the Table12 with 141, 80, 65 and 64 errors, respectively. 
Am. J. of Economics and Business Administration 3 (1): 40-46, 2011

Table 8: High critical error checkpoint 1.1 (image, alt)

\begin{tabular}{ll}
\hline Type & No of error (lines) \\
\hline Federal & 139 \\
State & 136 \\
Federal & 123 \\
State & 107 \\
State & 105 \\
\hline
\end{tabular}

Table 9: High critical error for checkpoint 3.4 (Table, Border)

\begin{tabular}{ll}
\hline Type & No of error (lines) \\
\hline Federal & 104 \\
Federal & 97 \\
Federal & 87 \\
State & 83 \\
Federal & 83
\end{tabular}

Table 10: High critical error for checkpoint 3.4 (Table, Cell padding)

\begin{tabular}{ll} 
Type No of error (lines) \\
\hline
\end{tabular}

Federal

Federal

Federal

State

Federal

Table 11: Checkpoint 3.4 (Table, Width)

\begin{tabular}{ll}
\hline Type & No of error (lines) \\
\hline Federal & 62 \\
State & 48 \\
Federal & 46 \\
State & 42 \\
State & 40 \\
\hline
\end{tabular}

Table 12: Checkpoint 10.1 (A, Target)

\begin{tabular}{ll}
\hline Type & No of error (lines) \\
\hline Federal & 141 \\
Federal & 80 \\
Federal & 65 \\
Federal & 64 \\
State & 57 \\
\hline
\end{tabular}

Table 13: Checkpoint 11.2 (Font)

\begin{tabular}{ll}
\hline Type & No of error (lines) \\
\hline State & 862 \\
State & 186 \\
Federal & 182 \\
State & 156 \\
State & 130 \\
\hline
\end{tabular}

Table 14: Checkpoint 12.4 (Input, Id)

\begin{tabular}{ll}
\hline Type & No of error (lines) \\
\hline State & 39 \\
Federal & 31 \\
State & 23 \\
State & 21 \\
State & 20 \\
\hline
\end{tabular}

E-Government website with high critical error for checkpoint 11.2 (Font): State government website violates the most for "Checkpoint 11.2 (Font)", as shown in Table 13, with 862 errors. Here, the websites from state government dominates the Table 13 by
Table 15: Cross tabulation analysis (Federal/State)

\begin{tabular}{|c|c|c|c|c|c|}
\hline \multirow[b]{3}{*}{ Checkpoint } & \multirow[b]{3}{*}{ Violate } & \multicolumn{4}{|c|}{ Government type } \\
\hline & & \multicolumn{2}{|c|}{ Federal } & \multicolumn{2}{|l|}{ State } \\
\hline & & Count & $\begin{array}{l}\text { Within } \\
\text { type }(\%)\end{array}$ & Count & $\begin{array}{l}\text { Within } \\
\text { type (\%) }\end{array}$ \\
\hline \multicolumn{6}{|l|}{3.4} \\
\hline \multirow[t]{2}{*}{ (Table, Width) } & $\mathrm{Y}$ & 22 & 88.0 & 94 & 72.3 \\
\hline & $\mathrm{N}$ & 3 & 12.0 & 36 & 27.7 \\
\hline $\begin{array}{l}\text { Total } \\
10.1\end{array}$ & & 25 & 100.0 & 130 & 100.0 \\
\hline \multirow[t]{2}{*}{ (A, Target) } & Y & 22 & 88.0 & 93 & 71.5 \\
\hline & $\mathrm{N}$ & 3 & 12.0 & 37 & 28.5 \\
\hline Total & & 25 & 100.0 & 130 & 100.0 \\
\hline 11.2 & & & & & \\
\hline \multirow[t]{2}{*}{ (Font) } & $\mathrm{Y}$ & 19 & 76.0 & 91 & 70.0 \\
\hline & $\mathrm{N}$ & 6 & 24.0 & 39 & 30.0 \\
\hline Total & & 25 & 100.0 & 130 & 100.0 \\
\hline \multirow[t]{2}{*}{ (Input, Id) } & $\mathrm{Y}$ & 20 & 80.0 & 82 & 63.1 \\
\hline & $\mathrm{N}$ & 5 & 20.0 & 48 & 36.9 \\
\hline Total & & 25 & 100.0 & 130 & 100.0 \\
\hline
\end{tabular}

violating the checklist the most as compared to state government with 186, 156 and 130 errors, respectively.

E-Government website with high critical error for checkpoint 12.4 (Input, Id): As shown in Table 14, state government website led the ranking of violating "Checkpoint 12.4 (Input, Id)" with 39 errors. Here, the websites from state government dominates the Table 14 by violating the checklist the most as compared to state government with 23, 21 and 20 errors, respectively.

Accessibility error (federal/state): As shown in Table 15, only checkpoint 3.4, checkpoint 10.1, checkpoint 11.2 and checkpoint 12.4 are valid and meet the assumption for the data interpretation as suggested by Pallant (2008) for cross tabulation analysis. The findings also revealed that websites under federal government may need to increase the accessibility level of the sites compared to state government due to the high number of accessibility errors reported in this study. This assumption is based of the comparison made with the percentage of error showed for Federal websites are higher than state websites for the checklist as shown in Table 15.

\section{DISCUSSION}

Ensuring accessibility and usability of the service provided for people with disability should be among key aspects of Malaysian e-government. There is a need to raise the level of awareness towards increasing the number of accesses and usable participation of all 44 
high number of usability (speed and number of broken links) and accessibility problems for state website upon comparing to federal website. Thus, further improvement has to be made by web developer so that the e-government websites are more accessible and convenient to use. Relevant government readiness assessment model (Al-Omari and Al-Omari, 2006) may be feasible to provide grounding assessment.

\section{CONCLUSION}

The findings reported in this study may alert web developer for Malaysia e-government websites to give more emphasis on specific accessibility and usability features which are often being neglected. The limitation of this study is on the quantitative measure used to assess accessibility which is only subjected to WCAG 1.0 guideline. This is due to the limitation on the availability of the automatic tool that supports WCAG 2.0. Future research should also consider evaluating the website accessibility based on WCAG 2.0 guidelines. The issues and recommendations highlights for further improvement of the usability and accessibility level in government websites may also be taken into consideration towards ensuring that e-government delivers for all citizens especially for citizens with disabilities.

\section{REFERENCE}

Abanumy, A., A. Al-Badi and P. Mayhew, 2005. EGovernment website accessibility: In-depth evaluation of Saudi Arabia and Oman. Elect. J. EGovern., 3: 99-106. ISSN: 1479-439X

Ahmad Bakeri, A.B., 2008. Evaluation of Federal and State E-Government Websites in Malaysia. In: Proceeding of the 4th International Conference on e-Government, D. Remenyi (Eds.). Academic Conferences Limited, pp: 9-16. ISBN: 9781906638207

Alexander, D., 2003. How Accessible are Australian University Web Sites? In: Proceeding of AusWeb03, the Ninth Australian World Wide Web Conference Lismore, A. Treloar and A. Ellis (Eds.). AusWeb03: Changing the way we work: Australia Southern Cross University, pp: 71-82. ISBN: 1863844937

Al-Omari, A. and H.E. Al-Omari, 2006, Government readiness assessment model. J. Comput. Sci., 2: 841-845. DOI: 10.1.1.131.357
Becker, A., 2008. Accessibility of Federal Electronic Government. Digital Government: E-Government Research. In: Case Studies and Implementation, Chen, H., L. Brandt, V. Gregg, R. Traunmuller, S. Dawes and E. Hovy et al., (Eds.). Digital Government, Springer, vol. 17, pp: 141-155. DOI: 10.1007/978-0-387-71611-4_8

Blackstone, E., A.M. Bognanno and S. Hakim, 2005. Innovations in E-government: the Thoughts of Governors and Mayors. 1st Edn., Rowman and Littlefield, ISBN: 9780742549135

Carter, J. and M. Markel, 2001. Web accessibility for people with disabilities: An introduction for web developers. IEEE Trans. Prof. Commun., 44: 225-233. DOI: 10.1109/47.968105

Centeno, V.L., C.D. Kloos, M. Gaedke and M. Nussbaumer, 2005. WCAF Formalization with W3C Techniques. In: Web Engineering, D. Lowe and M. Gaedke (Eds.). Springer-Verlag Berlin Heidelberg, pp: 615-617. DOI: 10.1007/11531371_84

Chen, Y.L., Y.Y. Chen and M. Shao, 2005. Accessibility diagnosis on the government web sites in Taiwan, ROC. ACM Int. Conf. Proceed. Series, $\quad 134$ : 132-142. DOI: 10.1145/1133219.1133243

Koga, T., 2006. Policy issues regarding electronic government and Web accessibility in Japan. Proceeding of the World Library and Information Congress: 72nd IFLA General Conference and Council. Seoul, Korea, Aug. 20-24, http://hdl.handle.net/2433/70381

Kopackova, H., K., Michalek and K. Cejna, 2009. Accessibility and findability of local e-government websites in czech republic, springer-verlag. Univ. Access Inform. Soc., 9: 51-61. DOI: 10.1007/s10209-009-0159-y

Korsten, H. and T.J.D. Bothma, 2007. Evaluating south african government web sites: Methods, findings and recommendations (Part 2). South African J. Inform. Manage., 7: 3. ISSN: 1560-683X

Latif, M.H.A. and M.N. Masrek, 2010. Accessibility evaluation on Malaysian E-Government websites, J. E-Government Stud. Best Practices, 2010: 11. ISSN: 2155-4137

Lee, S., B.G. Kim and J.G. Kim, 2007. Accessibility Evaluation of Korean E-Government. In: Universal Access in HCI, Part III, C. Tephanidis (Ed.). HCII 2007, LNCS 4556, Springer-Verlag Berlin Heidelberg, pp: 73-78. DOI: 10.1007/978-3-54073283-9_9 
Nasir, M.H.N.M., H. Hassan and N. Jomhari, 2008. The use of mobile phones by elderly: A study in Malaysia perspectives. J. Soc. Sci., 4: 123-127. DOI: 10.3844 jssp.2008.123.127

Nielson, J., 1994. Usability Engineering. 1st Edn., Morgan Kaufmann, ISBN: 0-12-518406-9, pp: 362.

Nielson, J., 2000. Designing Web Usability. 1st Edn., New Riders Publishing, ISBN-13: 9781562058104, pp: 419.

Nordin, M.J. and A.M. Ali, 2009. Indoor navigation and localization for visually impaired people using weighted topological map. J. Comput. Sci., 5: 883-889. DOI: $10.3844 /$ jcssp.2009.883.889

Pallant, J., 2008. SPSS Survival Manual: A Step by Step Guide to Data Analysis Using SPSS for Windows (Version 15). 1st Edn., Open University Press, ISBN: 0335208908, pp: 352.

Paris, M., 2006. Website accessibility: A survey of local e-government websites and legislation in Northern Ireland, universal access in the information society. Springer-Verlag Berlin Heidelberg, 4: 292-299. DOI: 10.1007/s10209-0030081-7

Potter, A., 2002. Accessibility of Alabama government web sites. J. Govern. Inform., 29: 303-317. DOI: 10.1016/S1352-0237(03)00053-4

Robbins, J.N., 2006. Web Design in a Nutshell. 3rd Edn., O'Reilly Media, Inc, ISBN: 10: 0-59600987-9, pp: 796.

Shah, B.P. and S. Shakya, 2007. Evaluating the web accessibility of websites of the central government of Nepal. Proceeding of the 1st International Conference on Theory and Practice of Electronic Governance, Macao,10-13 Dec. 2007, ACM International Conference Proceeding Series, pp: 447-448. DOI: $10.1145 / 1328057.1328154$
Shi, Y., 2006. E-government web site accessibility in Australia and china: A longitudinal study. Soc. Sci. Comput. Rev., 24: 378-385. DOI: $10.1177 / 0894439305283707$

Shi, Y., 2007. The accessibility of Chinese local government web sites: An exploratory study. Govern. Inform. Q., 24: 377-403. DOI: 10.1016/j.giq.2006.05.004

Siau, K. and Y. Long, 2006. Using social development lenses to understand e-government development. J. Global Inform. Manage., 14: 47-62. ISSN: 10627375

Thatcher, J., 2002. Constructing accessible web sites. http://jimthatcher.com/book.htm

Tillett, L.S., 2001. Web accessibility ripples through it. Internet Week, 848, 1. Retrieved August, 20, 2009. http://www.webaim.org/intro/

Wan Abdul Rahim, W. M. I., M. N. Nor Laila and M. Shafie, 2009a. Cultural prescription Vs user perception of information architecture for culture centered website: A Case Study on Muslim Online Use. In: Online Communities and Social Computing. Social Behavior in On-line Communities, A. Ant Ozok, Panayiotis Zaphiris (Eds.). LNCS 5621, Springer-Verlag Berlin, pp: 535-544. DOI: 10.1007/978-3-642-02774-1_58

Wan Abdul Rahim, W.M. I., S.M. Rashideen and S. Noor Ilyani, 2010. Evaluating the Accessibility of Malaysia E-Government Website. In: Proceedings of Knowledge Management International Conference (KMICe), F. Baharom, M. Mahmuddin, Y. Yusof, Wan Hussain, W. I \& M. Ali Saip (Eds.). University Utara Malaysia, 2010, ISBN: 978-983-2078-39-5, pp: 567-572.

Wan Abdul Rahim, W.M.I., M.N. Nor Laila and M. Shafie, 2009b. Culture design of information architecture for $\mathrm{B} 2 \mathrm{C}$ ecommerce websites. In Human Centered Design. Evaluation and Assessment, Masaaki Kurosu (Ed.). LNCS 5619, Springer-Verlag Berlin, pp: 805-814. DOI: 10.1007/978-3-642-02806-9_93 